- Shakes peare's foreign Worlds 



\title{
SHAKESPEARE'S FOREIGN WORLDS
}

\author{
NATIONAL AND \\ TRANSNATIONAL \\ IDENTITIES IN THE \\ ELIZABETHAN AGE
}

CAROLE LEVIN AND JOHN WATKINS 


\section{Copyright (C) 2009 by Cornell University}

All rights reserved. Except for brief quotations in a review, this book, or parts thereof, must not be reproduced in any form without permission in writing from the publisher. For information, address Cornell University Press, Sage House, 512 East State Street, Ithaca, New York 14850.

First published 2009 by Cornell University Press

Printed in the United States of America

Library of Congress Cataloging-in-Publication Data

Levin, Carole, 1948-

Shakespeare's foreign worlds : national and transnational identities in the Elizabethan age / Carole Levin and John Watkins.

p. $\mathrm{cm}$.

Includes bibliographical references and index.

ISBN 978-0-8014-4741-9 (cloth : alk. paper)

1. Shakespeare, William, 1564-1616-Characters.

2. Characters and characteristics in literature. 3. Group identity in literature. 4. National characteristics, English, in literature. 5. National characteristics in literature. 6. Aliens in literature. 7. Literature and history-England-History-16th century. I. Watkins, John, 1960- II. Title.

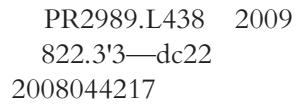

Cornell University Press strives to use environmentally responsible suppliers and materials to the fullest extent possible in the publishing of its books. Such materials include vegetable-based, low-VOC inks and acid-free papers that are recycled, totally chlorine-free, or partly composed of nonwood fibers. For further information, visit our website at www.cornellpress.cornell.edu.

Cloth printing $\quad 1098876554321$ 
This book is for Michele Osherow, who taught me about Eve Cohan, and for the women of the Bvinovitch clan, especially the young matriarch and the tiniest Bvinovitch girl, who have successfully sojourned in so many foreign worlds Carole

In memory of my teachers Stuart Sperry and Albert Wertheim John 
